cotton manufacture in a single plant. As a result of his enterprise there was developed at Waltham, by Paul Moody and other mechanics, a series of textile machines highly original in construction and differing in many respects from earlier British models; but in constructing the power loom Lowell, while introducing a number of novel features, built upon the previous inventions of Cartwright, Horrocks, and other English and Scotch mechanics. Moreover, in the later modifications of the Waltham loom, Paul Moody not only made use of his own patented improvements, but borrowed from a number of American inventors who were in no way connected with the Boston Manufacturing Company. This fact is made clear by a letter written to Patrick Tracy Jackson, in 1830 , by James Stimson and by agreements with the owners of other patents, among whom appear the important names of Jacob Perkins and Ira Draper. The number of items referring to early technical advance is small, but the fact that any of these original documents have survived for more than a century gives rise to the hope that other similar papers may have escaped destruction, and that by the concerted effort of individual members of the Business Historical Society, the collection already deposited in the Baker Library may be greatly enriched.

\title{
Zn fllemoriam
}

ON JuLY thirty-first last the Society suffered the loss by death of one of its most prominent members. It is with profoundest regret that we announce the passing of Mr. Rodolphe Louis Agassiz, Chairman of the Board of the Calumet \& Hecla Consolidated Copper Company, who became a member of our organization in June, 1929. His untimely death at the age of sixty-two cut short a notable business career.

Mr. Agassiz entered the employ of the Calumet \& Hecla Mining Company immediately after his graduation from Harvard in 1892 and soon became a member of the executive staff as assistant to the President of that corporation. In 1916 he became the President of the company, succeeding his father, Mr. Alexander Agassiz; and when the Calumet \& Hecla Mining Company was consolidated with a number of other copper companies in 1926 , he became Chairman of the Board of the Calumet \& Hecla Consolidated Copper Company, retaining the executive control of the company until his death. He was actively interested in the promotion of efficiency of 
operation, goodwill, and a better understanding among the copper producers and manufacturers, and in this effort occupied the positions of President, Director, and Chairman of the Executive Committee and member of the Advisory Committee of the Copper and Brass Research Association; President and Director of the Copper Export Association, Inc.; Director of the Copper Exporters, Inc.; Director and member of the Executive Committee of the Copper Institute; member of the Advisory Committee of the American Bureau of Metal Statistics, and Director of the Copper Producers Association. In addition to these interests he was a Director of the State Street Trust Company, the First National Bank of Boston, the Edison Electric Illuminating Company, Vice-President of the Massachusetts Hospital Insurance Company, and President and Director of several of the copper corporations with which his company was allied.

In the field of sport Mr. Agassiz is perhaps best remembered as one of the outstanding polo players in America, although in his later years he was a tennis and golf enthusiast. A polo team, sponsored by the Myopia Hunt Club, of which he was captain, captured the Senior Championship of the United States in 1895 and again in 1904 under his leadership duplicated this achievement. In I 902 he was selected to represent the Myopia Hunt Club on a team developed at the Rockaway Polo Club for an international match with England. His associates on this team were Messrs. Foxhall Keene (captain), J. M. Waterbury, Jr., Lawrence Waterbury and J. E. Cowdin and their success is a well remembered chapter in polo history.

Although a Republican at heart, his opposition on the prohibition question as legislated by his party was so pronounced as to warrant his allegiance with the Democratic party in 1928. During that year wide publicity was given to a statement made by him as a Director of the Constitutional Liberty League, the truth of which is now being amply verified by the heavy majorities in favor of the repeal of the Eighteenth Amendment which the states are now recording.

Mr. Agassiz was a man whose genial temperament and delightful disposition readily attracted hosts of friends who will mourn his passing. The intimate friendships of his college career lasted throughout his life, and this after all is the supreme test of a man's personality. The business world has suffered a great loss and we in the Business Historical Society feel that loss the more keenly because we counted him among our best friends. 